\title{
医道白寿4：医道白寿企画 4 「難治性精巣腫瘍」
} 21 日（木）第5会場

\author{
座長のメッセージ \\ 難治性精巣腫瘍 過去、現在、展望〜
}

\section{和歌山県立医科大学泌尿器科”，筑波大学 ${ }^{2}$}

原 勲 ${ }^{1)}$, 河合 弘二2)

精巣腫瘍はまれな疾患ではあるが、青壮年期に多いことより社会的な意義は大きい。転移を有する精巣腫瘍の予後は極めて不良であった が、1970 年代後半にシスプラチンが導入され予後は飛躍的に改善された。さらにエトポシドが導入され標準療法としてのBEP 療法が確立さ れてからは、完全寛解率が 70-80\% と転移を有する固形腫瘍の中では最も治癒が期待できる腫瘍となった。50歳以上の会員諸氏は多かれ少 なかれその変遷の凄まじさを実感されていることと思う。こうした時代の軌跡に関し山口大学名誉教授の内藤先生にアーカイブレクチャー を扮願いした。BEP 療法の有用性については今さら言及するまでもないが、見過ごされやすいこととして初期治療としてのBEP 療法を如何 に確実に完遂するかという問題がある。精巣腫瘍を多数扱っている施設では、初期治療が不十分に施行されたために完治に至らず紹介されて くる患者が後を経たない。初期治療としてのBEP 療法を如何に速やかに完遂するかに関し東北大学の山田先生に工夫点につき述べてもら う。BEP 療法を施行しても完全寛解に至らない 20-30\%の症例においては救済化学療法が必要となる。さらにBEP 療法にて完全寛解に至っ た後に再発してくる症例もありこれらを含めて難治性精巣腫瘍と定義している。救济化学療法としては従来 VIP 療法やVeIP 療法が用いら れてきたが満足な治療成績とは言えなかった。次に登場してきたのが末梢血幹細胞移植併用超大量化学療法であるが、その有用性に関しては いくつかの第3 相臨床試験の結果、完全に否定されたわけではないが証明できなかった。近年注目を浴びているのがタキソールをレジメンに 加えたTIP 療法であり国内外のガイドラインも TIP 療法を推奨している。しかしながら TIP 療法の有用性に関しては第 3 相臨床試験にて 確認されたわけではなくやはり今後の検討が必要である。導入化学療法にて完全寛解に至らなかった症例に対する救済化学療法としての TIP 療法の治療成績に関し、筑波大学から及川先生に発表していただ。また完全寛解後の再発例に対する救済化学療法につき神戸大学の村 蒔先生から発表していたたく。さらに後腹膜リンパ節廓清を主体とした手術療法に関しては原則、マーカーが陰性化した後に行うこととされ ている。しかしながら複数種類の抗癌化学療法にも関わらずマーカーが陰性化しない症例に関しては最後の望みとして手術療法の選択肢も 考慮しなければならない。実際には難しい点が多々ある治療選択であるが、この点に関しても多数の経験をお持ちの京都府立医科大学の中村 先生から発表していただく。これらの発表を通じて難治性精巣腫瘍の現状と問題点に関し新たな知見を得ていただければ幸いである。

\section{第 1 部 : アーカイブレクチャー 医道白寿4-1 \\ 21 日 (木) 第5会場}

\section{有転移精巣腫瘍との格闘の軌跡}

\section{山口大学名誉教授1), 美袮市立病院 ${ }^{21}$}

内藤 克輔 ${ }^{12}$,

精巣腫瘍の $90 \%$ 以上は、胚細胞由来の悪性腫瘍であり、男性の悪性腫瘍の $1 \%$ を占めるにすぎない比較的稀な疾患 である。精巣にはSeminoma、胎児性癌、卵黄囊腫、奇形腫等が発生し、その他に、rhabdomyosarcomaも見られ、多 種多様の腫湯が発生する。

財団法人がん研究振興財団より毎年発行される「がんの統計」の 2009 年版に、2007 年度のICD-10に準じた各臓器 別に見た癌死亡数が揭載された。男性性器の癌による死亡数は、㓌茎：128人、前立腺： 8,418 人、精巣：87人と報告 され、精巣腫瘍は男性の全悪性腫瘍の $0.01 \%$ 弱を占めるのみであり、比較的稀な腫瘍である。

精巣腫瘍に対する治療法の変遷をたどると、高位精巣摘除術と放射線の外照射治療が主であったが、1977 年にCisplatin が導入され、生存率は飛躍的に延長し、さらに難治症例に対する自家末梢血幹細胞の移植（PBSCT）を併用し た抗癌化学療法にて完全緩解、さらに残存腫瘍組織の摘出や後腹膜腔リンパ節廓清術により長期生存が得られるよう になった。現在用いられている主な薬剂は、Cisplatin, Etoposide, Ifosfamide, Bleomycin、等であるが、抗がん剂の 副作用による骨髄抑制は G-CSF 投与で改善でき、強力な抗癌化学療法が可能となった。しかし、各種の抗癌化学療法 や放射線療法、さらには末梢血幹細胞移植を用いた大量化学療法を用いても完全緩解には到らず、その後に遠隔転移 を発生する症例も少なからず経験する。

高濃度の Etoposide に続いて Ifosfamide およびCisplatin を患者に併用投与する（VIP）抗癌化学療法に末梢血幹細 胞 (PBSC) を併用投与すると、良好な治療効果をもたらす。未治療の転移を有する精巣腫瘍患者 53 例に、3 週間隔で 2-4 サイクルが (平均 3 サイクル) 投与された。脳転移を有する患者は同時に放射線療法を受けた。 2 年及び 5 年生 存率は、それぞれ 77.6\% および 75.2\% であった（Kaushal Raj Pandey. The Lancet Oncology, 9 (2) : 98, 2008.)。

ヨーロッパでの 20,435 例で検討された精巣腫瘍 5 年相対生存率は $93.8 \%$ であった。 